\section{PENINGKATKAN KEMAMPUAN GURU}

\section{- DALAM MELAKSANAKAN}

\section{PENILAIAN AUTENTIK MELALUI} SMALL GROUP DISCUSSION

Buku ini merupakan karya tulis peneliti yang mengemban tugas sebagai Pengawas MTs dan MA di Kantor Kementerian Agama Kota Tegal Jawa Tengah dalam melaksanakan tugas kepengawasannya terhadap guru-guru mitra kerjanya. Buku ini adalah karya tulis dalam bentuk Penelitian Tindakan Kepengawasan ditujukan untuk membantu guru agar memiliki kemampuan melakukan penilaian autentik. Kemampuan penilaian autentik melalui observasi, monitoring dan evaluasi serta bimbingan terhadap guru dengan pendekatan small group discussion, harapannya agar kesulitan dan tantangan yang berakibat pada rendahnya hasil pembelajaran teratasi secara tuntas.

Penulis berkeyakinan, dengan menerapkan penelitian tindakan kepengawasan, maka permasalahan dalam melaksanakan penilaian autentik dapat diatasi tidak hanya secara tepat tetapi dengan menggunakan pendekatan keilmuan yang dapat dipertanggungjawabkan berdasarkan kaidah-kaidah keilmuwan pula. Hal ini mengandung arti bahwa pengawas tidak hanya melakukan tindakan kepengawasan secara professional, tetapi berusaha mengembangkan profesionalitas terhadap guru-guru yang menjadi mitra kerjanya dengan menggunakan pendekatan small group discussion.

Dengan hadirnya buku ini, diharapkan menjadi pendorong bagi para pengawas sekolah/ madrasah dalam memahami keseluruhan proses penelitian Tindakan kepengawasan dalam upaya memecahkan masalah yang dihadapi dan sekaligus mengembangkan secara professional kemampuan diri guru di dalam melaksanakan tugas pokok di sekolah/madrasah.
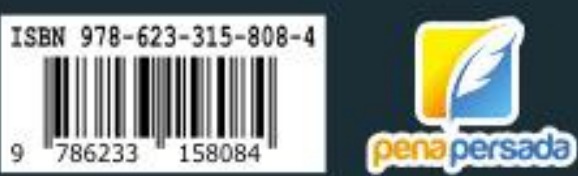

\section{LUTFIYAH NUR ROCHMAH, M.Pd.}

penapersada

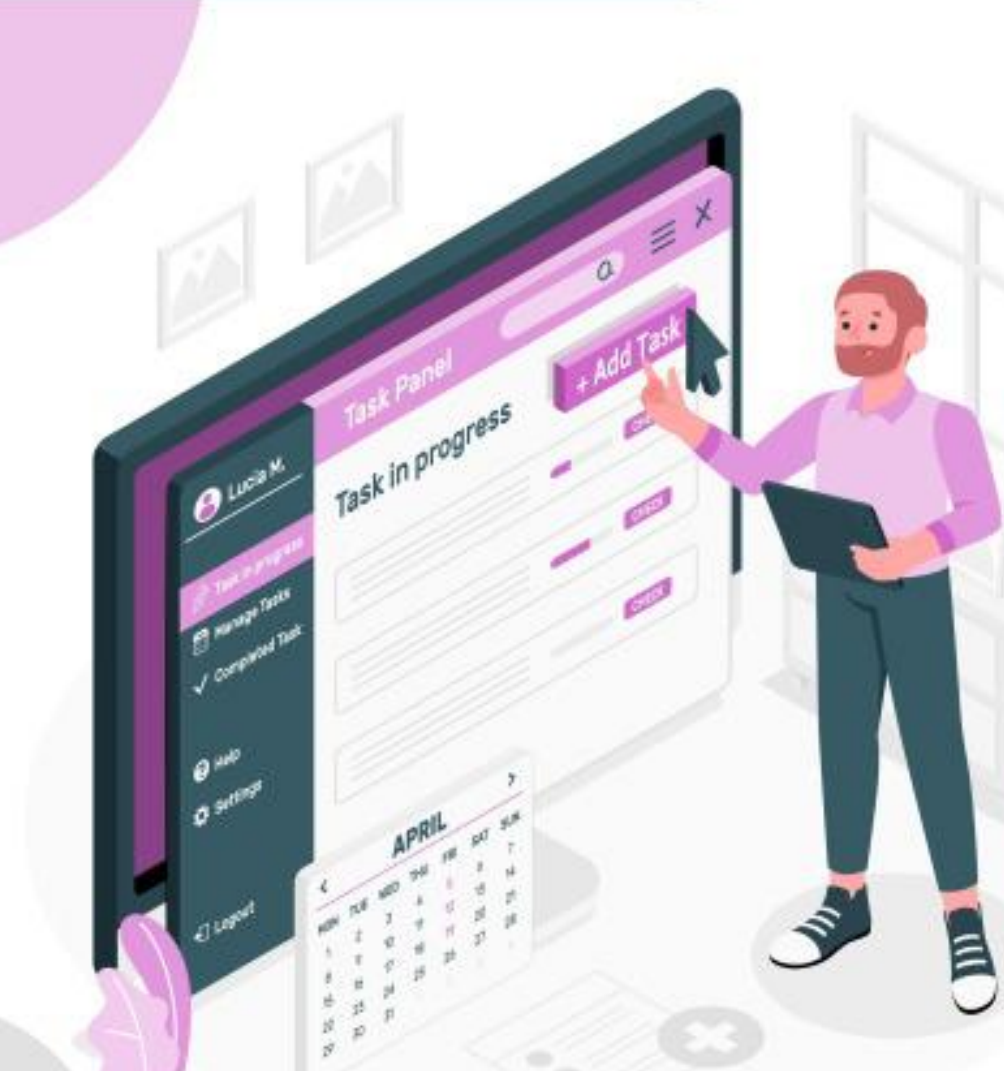

\section{PENINGKATKAN KEMAMPUAN GURU}

DALAM MELAKSANAKAN

\section{PENILAIAN AUTENTIK MELALUI}

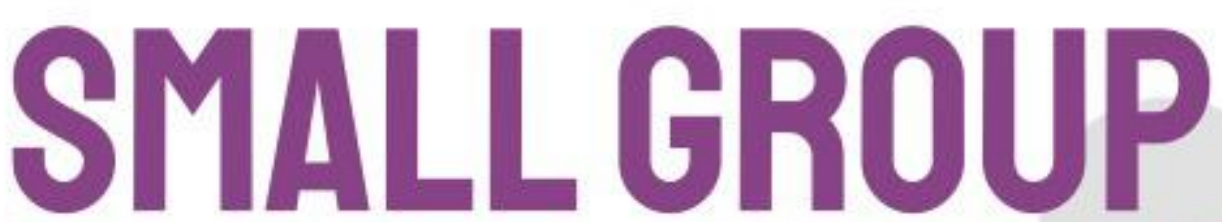
DISCUSSION 


\section{PENINGKATKAN KEMAMPUAN GURU \\ DALAM MELAKSANAKAN PENILAIAN AUTENTIK MELALUI SMALL GROUP DISCUSSION}

Lutfiyah Nur Rochmah, M.Pd.

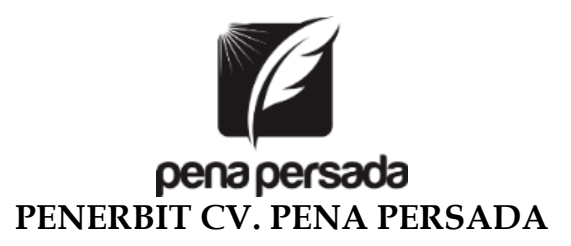




\title{
PENINGKATAN KEMAMPUAN GURU \\ DALAM MELAKSANAKAN PENILAIAN AUTENTIK MELALUI SMALL GROUP DISCUSSION
}

\author{
Penulis: \\ Lutfiyah Nur Rochmah, M.Pd.
}

ISBN: 978-623-315-808-4

Editor:

Mutolib

Design Cover:

Retnani Nur Briliant

\author{
Layout: \\ Hasnah Aulia
}

\section{Penerbit CV. Pena Persada \\ Redaksi:}

Jl. Gerilya No. 292 Purwokerto Selatan, Kab. Banyumas

Jawa Tengah

Email: penerbit.penapersada@gmail.com

Website: penapersada.com Phone: (0281) 7771388

Anggota IKAPI

All right reserved

Cetakan pertama: 2021

Hak Cipta dilindungi oleh undang-undang. Dilarang memperbanyak buku ini dalam bentuk apapun tanpa izin penerbit 


\section{KATA PENGANTAR}

Segala puji senantiasa kita panjatkan Kehadirat Tuhan Yang Maha Esa, atas segala Rahmat dan Karunia-Nya, akhirnya penulis dapat menyelesaikan penyusunan buku yang berjudul "PENINGKATAN KEMAMPUAN GURU DALAM MELAKSANAKAN PENILAIAN AUTENTIK MELALUI SMALL GROUP DISCUSSION" Penulis menyadari bahwa tanpa bantuan dan bimbingan dari berbagai pihak sangatlah sulit bagi penulis untuk menyelesaikan buku ini. Oleh karena itu, penulis mengucapkan terima kasih atas penghargaan dan dukungan serta Kerjasama pada semua pihak yaitu Kepala Kantor kementerian agama Kota Tegal Kepala Madrasah yang terkait dengan pelaksanaan penelitian, para guru yang telah berpartisipasi aktif secara keseluruhan dalam penelitian. Sehingga buku ini bisa hadir di hadapan pembaca.

Buku ini merupakan karya tulis peneliti yang mengemban tugas sebagai Pengawas MTs dan MA di Kantor Kementerian Agama Kota Tegaldalam pengawasannya terhadap guru-guru mitra kerjanya. Karya tulis dalam bentuk Penelitian Tindakan Kepengawasan ditujukan untuk membantu guru agar memiliki kemampuan melakukan penilaian autentik. Kemampuan penilaian autentik melalui observasi, monitoring dan evaluasi serta bimbingan terhadap guru dengan pendekatan small group discussion, harapannya agar kesulitan dan tantangan yang berakibat pada rendahnya hasil pembelajaran teratasi secara tuntas.

Penulis berkeyakinan, dengan menerapkan penelitian tindakan kepengawasan, maka permasalahan dalam melaksanakan penilaian autentik dapat diatasi tidak hanya secara tepat tetapi dengan menggunakan pendekatan keilmuan yang dapat dipertanggungjawabkan berdasarkan kaidah-kaidah keilmuwan pula. Hal ini mengandung arti bahwa pengawas tidak hanya melakukan tindakan kepengawasan secara professional, tetapi berusaha mengembangkan profesionalitas terhadap guru-guru yang menjadi mitra kerjanya dengan menggunakan pendekatan small group discussion. 
Dengan hadirnya buku ini diharapkan menjadi pendorong bagi para pengawas sekolah/ madrasah di dalam memahami keseluruhan proses penelitian Tindakan kepengawasan dalam upaya pemecahan masalah yang dihadapi sekaligus mengembangkan kemampuan professional diri guru di dalam melaksanakan tugas pokoknya.

Penulis menyadari sepenuhnya dalam buku ini masih terdapat kekurangan ataupun kelemahan. Oleh karena itu, penulis mengharapkan kritik dan saran dari para pembaca untuk penyempurnaan buku ini. Penulis berharap, buku ini dapat memberikan motivasi untuk para pembaca dan berguna untuk kemajuan pendidikan di Indonesia. 


\section{DAFTAR ISI}

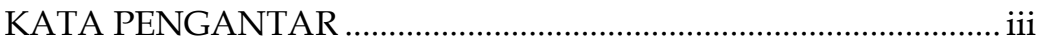

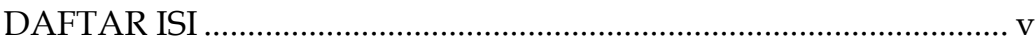

BAB 1 PENDAHULUAN …............................................................ vi

A. Penerapan Kurikulum 2013 ......................................................

B. Kemampuan Guru Dalam Pelaksanaan Penilaian Autentik 2 BAB II KONSEP PENILAIAN AUTENTIK DAN SMALL GROUP

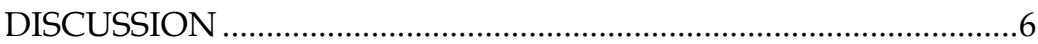

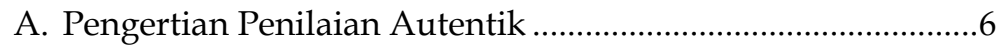

B. Lingkup Penilaian Autentik ..................................................

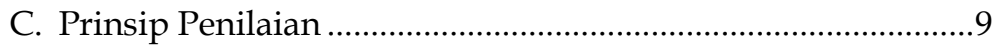

D. Bentuk Penilaian .....................................................................10

E. Mekanisme Penilaian ..................................................................11

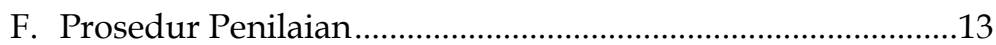

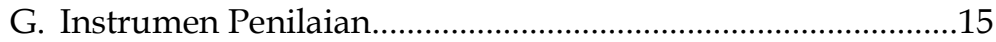

H. Madrasah Tsanawiyah .......................................................15

I. Small Group Discussion.........................................................17

BAB III INDIKATOR KEBERHASILAN DAN RANCANGAN

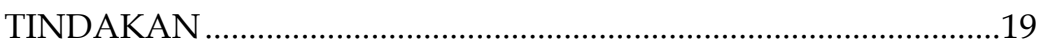

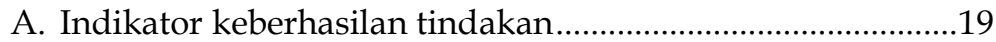

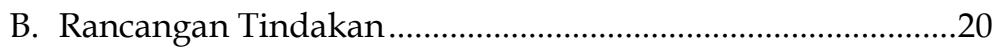

BAB IV PELAKSANAAN PENILAIAN AUTENTIK .......................22

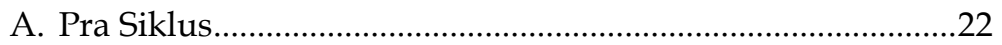

1. Profil Madrasah Tsanawiyah ........................................22

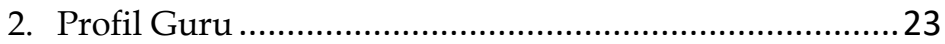

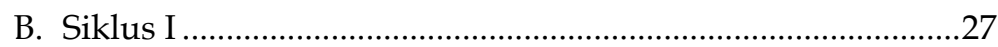

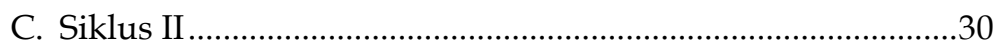

BAB V PELAKSANAAN SMALL GROUP DISCUSSION ...............35

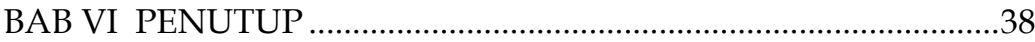

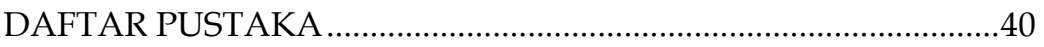




\section{PENINGKATKAN KEMAMPUAN GURU}

DALAM MELAKSANAKAN PENILAIAN AUTENTIK

MELALUI SMALL GROUP DISCUSSION 


\section{BAB 1 \\ PENDAHULUAN}

\section{A. Penerapan Kurikulum 2013}

Pemerintah Republik Indonesia memberlakukan kurikulum 2013 pada sekolah dan madrasah secara serentak mulai tahun pelajaran 2014/2015 untuk Kelas I dan kelas IV jenjang Sekolah Dasar / Madrasah Ibtidaiyah, Kelas VII untuk jenjang Sekolah Menengah Pertama / Madrasah Tsanawiyah, dan Kelas X untuk jenjang Sekolah Menengah Atas / Madrasah Aliyah, Sekolah Menengah Kejuruan / Madrasah Aliyah kejuruan. Lahirnya kurikulum 2013 merupakan jawaban atas berbagai persoalan yang terjadi di negeri ini, khususnya perilaku kenakalan remaja usia sekolah yang terekspos pada berbagai media, baik di lingkup sekolah maupun madrasah. Pelaksanaan Kurikulum 2013 yang dikenal dengan implementasi kurikulum 2013 (Kurtilas) pada Madrasah secara serentak dimulai pada tahun pelajaran 2014/2015 berdasarkan Keputusan Menteri Agama Republik Indonesia (KMA) Nomor 117 Tahun 2014 tanggal 14 Juli 2014 tentang Implementasi Kurikulum 2013 di Madrasah.

Implementasi kurikulum 2013 pada Kelas VII di Madrasah Tsanawiyah pada semester Tahun Pelajaran 2017/2018 dalam pelaksanaan di lapangan masih mengalami kendala. Hambatan yang paling dirasakan oleh guru sebagai ujung tombak dalam pelaksanaan Kurikulum 2013 ini khususnya pada perubahan standar penilaian. Guru sudah terbiasa menilai hasil belajar, dalam kurtilas menerapkan penilaian autentik. Standar Penilaian 
Pendidikan pada Permendikbud No. 23 tahun 2016 merupakan kriteria mengenai lingkup, tujuan, manfaat, prinsip, mekanisme, prosedur, dan instrumen penilaian hasil belajar peserta didik yang digunakan sebagai dasar dalam penilaian hasil belajar peserta didik pada pendidikan dasar dan pendidikan menengah (Lampiran permendikbud 23/2016: 2).

\section{B. Kemampuan Guru Dalam Pelaksanaan Penilaian Autentik}

Kemampuan guru dalam melaksanakan penilaian autentik pada kompetensi sikap spiritual dan sikap sosial dengan mengambil sampel 23 guru masih belum memenuhi harapan yaitu dengan nilai rata-rata 28,31 untuk pelaksanaan penilaian sikap, untuk kompetensi pengetahuan diperoleh nilai rata-rata 65,69 dan kompetensi keterampilan memperoleh nilai rata-rata 37,75 .

Memperhatikan belum maksimalnya kemampuan guru madrasah tsanawiyah sasaran kurikulum 2013 dalam melakukan penilaian autentik, maka pengawas sebagai pembimbing guru dan kepala madrasah berkewajiban untuk mencari solusi dengan memanfaatkan agenda dan kegiatan madrasah, seperti waktu luang guru pada saat jam istirahat tidak mengajar, pada saat rapat Kepala Madrasah dengan guru, kegiatan in house training dan workshop, dan kegiatan Musyawarah Guru Mata Pelajaran di madrasah.

Mengingat tidak setiap saat pengawas bisa bertemu dengan kepala madrasah dan guru, maka strategi yang diambil adalah dengan memanfaatkan waktu di luar jam pelajaran terhadap guru yang pada hari kunjungan pengawas di madrasah sedang tidak masuk kelas sebagai 
sampelnya. Dalam hal ini pengawas menyampaikan kepada sumber data (guru), bahwa ia sedang melakukan bimbingan (penelitian). Jadi mereka yang diteliti mengetahui sejak awal sampai akhir tentang aktivitas peneliti (Sugiyono, 2010: 312). Adapun proses bimbingan terhadap guru yang dijumpai dengan pendekatan small group discussion (SGD). Strategi model small group discussion dalam pembelajaran, adalah salah satu strategi pembelajaran aktif dimana dalam proses pembelajaran peserta dibagi menjadi kelompok-kelompok kecil guna memecahkan dan mendiskusikan topik permasalahan. Permasalahan yang didiskusikan berupa materi (konsep dan penerapan) penilaian autentik kurikulum 2013.

Diskusi merupakan percakapan ilmiah oleh beberapa orang yang tergabung dalam satu kelompok untuk saling bertukar pendapat suatu masalah atau bersama-sama mencari pemecahan, mendapatkan jawaban atas masalah tersebut. Sedangkan diskusi kelompok (Group Discussion) dapat diartikan sebagai jalan untuk memecahkan suatu masalah yang memerlukan beberapa jawaban alternatif yang dapat mendekati kebenaran, yang dapat merangsang anggota untuk berfikir sistematis, kritis dan bersikap dalam menyumbangkan pikiran-pikirannya untuk memecahkan suatu permasalahan.

Untuk mengetahui peningkatan kemampuan guru dalam permasalahan yang dihadapi khususnya dalam penilaian autentik guru madrasah sasaran kurikulum 2013 di Kota Tegal, penulis mengambil judul dalam penelitian ini “Upaya Meningkatkan Kemampuan Guru dalam Melaksanakan Penilaian Autentik Pada MTs Swasta Implementasi Kurikulum 2013 Semester 1 Tahun Pelajaran 2017/2018 Melalui Small Group Discussion di Kota Tegal" 
Berdasarkan latar belakang masalah yang telah dipaparkan oleh penulis maka fokus permasalahan ini yaitu upaya Meningkatkan Kemampuan Guru dalam Melaksanakan Penilaian Autentik Pada MTs Swasta Implementasi Kurikulum 2013 Semester 1 Tahun Pelajaran 2017/2018 Melalui Small Group Discussion di Kota Tegal. Adapun subfokus dalam kajian ini adalah. 1) sejauh mana kemampuan guru Madrasah Tsanawiah Swasta Implementasi Kurikulum 2013 dalam memahami proses Penilaian autentik. 2). Seberapa besar peningkatan kemampuan guru Guru Madrasah Tsanawiah Swasta Implementasi Kurikulum 2013 dalam melaksanakan Penilaian autentik 2013 setelah melalui small group discussion.

Hasil kajian ini diharapkan dapat memberikan kontribusi Bagi Siswa; penilaian autentik sangat diperlukan untuk mengetahui gambaran atau deskripsi peserta didik secara komprehensif pada kompetensi sikap spiritual dan sikap sosialnya. Untuk memberi informasi kompetensi pengetahuan yang dikuasainya, dan untuk mengukur kompetensi keterampilan sebagai bekal dalam mengarungi kehidupan yang semakin kompleks seperti sekarang ini. Bagi Guru; Penilaian autentik sangat diperlukan untuk meningkatkan kemampuannya dalam mengamati perubahan dan kemajuan perilaku peserta didik, memperoleh informasi kompetensi yang dikuasai peserta didik dan mengembangkan potensi dan bakat keterampilan yang dimiliki oleh peserta didik, sehingga menghasilkan peserta didik yang memiliki budi pekerti yang baik, kreatif dan produktif. Bagi Madrasah dan Kementerian Agama; Manfaat teoritis yang diharapkan dapat diperoleh dari penelitian ini bermanfaat bagi penulis dalam membantu meningkatkan karir sebagai tenaga 
kependidikan di Kota Tegal dan juga bagi pendidik lain dalam rangka untuk meningkatkan pelaksanaan tugas dan profesionalisme dalam pendidikan. Manfaat praktis sebagai informasi dan masukan bagi Instansi Kementerian Agama dan Madrasah yang terkait kompetensi Guru dalam mengimplementasikan penilaian autentik Kurikulum 2013 yang merupakan kebijakan Pemerintah. 


\section{BAB II \\ KONSEP PENILAIAN AUTENTIK DAN \\ SMALL GROUP DISCUSSION}

\section{A. Pengertian Penilaian Autentik}

Peraturan Menteri Pendidikan dan Kebudayaan Nomor 23 Tahun 2016 tentang Standar Penilaian menjelaskan bahwa Standar penilaian pendidikan adalah kriteria mengenai lingkup, tujuan, manfaat, prinsip, mekanisme, prosedur, dan instrumen penilaian hasil belajar peserta didik yang digunakan sebagai dasar dalam penilaian hasil belajar peserta didik pada pendidikan dasar dan pendidikan menengah. Penilaian pendidikan sebagai proses pengumpulan dan pengolahan informasi untuk mengukur pencapaian hasil belajar peserta didik mencakup: penilaian autentik, penilaian diri, penilaian berbasis portofolio, penilaian harian, penilaian tengah semester, penilaian akhir semester, penilaian akhir tahun, ujian tingkat kompetensi, ujian mutu tingkat kompetensi, ujian nasional, dan ujian sekolah berstandar nasional dan ujian akhir madrasah berstandar nasional.

Penilaian autentik merupakan penilaian yang dilakukan secara komprehensif untuk menilai mulai dari masukan (input), proses, dan keluaran (output) pembelajaran. (Lampiran Permendikbud 23, 2016; 2)

Penilaian Autentik merupakan pendekatan utama dalam Penilaian Hasil Belajar yang dilakukan oleh Pendidik. Bentuk penilaian Autentik mencakup penilaian berdasarkan pengamatan, tugas ke lapangan, portofolio, projek, produk, jurnal, praktik, dan unjuk kerja, serta penilaian diri. 
Dari definisi tentang penilaian autentik di atas dapat diambil suatu kesimpulan bahwa penilaian autentik pada kurikulum 2013 merupakan penilaian yang harus dilakukan oleh guru/ pendidik selama proses pembelajaran di kelas melalui pengamatan/ observasi, penilaian diri peserta didik, penilaian antar peserta didik dan catatan jurnal, penilaian hasil belajar dalam bentuk tes tertulis, tes lisan dan penugasan untuk mengetahui kemajuan belajar peserta didik, dan dengan penilaian unjuk kerja/praktik, penilaian projek, penilaian produk, dan penilaian portofolio untuk mengukur keterampilan peserta didik, sehingga peserta didik dapat memiliki sikap (Akhlakul karimah), menggunakan pengetahuan dan keterampilan yang diperoleh dalam melakukan tugas/ pekerjaan.

\section{B. Lingkup Penilaian Autentik}

Penilaian pendidikan pada pendidikan dasar dan pendidikan menengah terdiri atas :

1. Penilaian hasil belajar oleh pendidik;

2. Penilaian hasil belajar oleh satuan pendidikan; dan

3. Penilaian hasil belajar oleh Pemerintah.

Menurut Peraturan Menteri Pendidikan dan Kebudayaan Nomor 23 Tahun 2016 tentang Penilaian Hasil Belajar peserta didik pada pendidikan dasar dan pendidikan menengah meliputi aspek: sikap, pengetahuan, dan keterampilan. Penilaian sikap merupakan kegiatan yang dilakukan oleh pendidik untuk memperoleh informasi deskriptif mengenai perilaku peserta didik, penilaian pengetahuan merupakan kegiatan yang dilakukan untuk mengukur penguasaan pengetahuan peserta didik, dan penilaian keterampilan 
merupakan kegiatan yang dilakukan untuk mengukur kemampuan peserta didik menerapkan pengetahuan dalam melakukan tugas tertentu. Penilaian pengetahuan dan keterampilan dilakukan oleh pendidik, satuan pendidikan, dan/ atau pemerintah.

Penilaian hasil belajar oleh pendidik bertujuan untuk memantau dan mengevaluasi proses, kemajuan belajar, dan perbaikan hasil belajar peserta didik secara berkesinambungan. Penilaian hasil belajar oleh satuan pendidikan bertujuan untuk menilai pencapaian Standar Kompetensi Lulusan untuk semua mata pelajaran. Penilaian hasil belajar oleh Pemerintah bertujuan untuk menilai pencapaian kompetensi lulusan secara nasional pada mata pelajaran tertentu.

Sasaran Penilaian Hasil Belajar oleh Pendidik pada dimensi pengetahuan adalah sebagai berikut :

\begin{tabular}{|l|l|}
\hline $\begin{array}{l}\text { Dimensi } \\
\text { Pengetahuan }\end{array}$ & Deskripsi \\
\hline Faktual & $\begin{array}{l}\text { Pengetahuan tentang istilah, } \\
\text { nama orang, nama benda, } \\
\text { angka, tahun, dan hal-hal yang } \\
\text { terkait secara khusus dengan } \\
\text { suatu mata pelajaran. }\end{array}$ \\
\hline Konseptual & $\begin{array}{l}\text { Pengetahuan tentang kategori, } \\
\text { klasifikasi, keterkaitan antara } \\
\text { satu kategori dengan lainnya, } \\
\text { hukum kausalita, definisi, teori. }\end{array}$ \\
\hline Prosedural & $\begin{array}{l}\text { Pengetahuan tentang prosedur } \\
\text { dan proses khusus dari suatu } \\
\text { mata pelajaran seperti } \\
\text { algoritma, teknik, metoda, dan } \\
\text { kriteria untuk menentukan }\end{array}$ \\
\hline
\end{tabular}




\begin{tabular}{|l|l|}
\hline & $\begin{array}{l}\text { ketepatan penggunaan suatu } \\
\text { prosedur. }\end{array}$ \\
\hline Metakognitif & $\begin{array}{l}\text { Pengetahuan tentang cara } \\
\text { mempelajari pengetahuan, } \\
\text { menentukan pengetahuan yang } \\
\text { penting dan tidak penting } \\
\text { (strategic knowledge), } \\
\text { pengetahuan yang sesuai }\end{array}$ \\
\hline
\end{tabular}

\section{Prinsip Penilaian}

Prinsip Penilaian Hasil Belajar sebagai berikut :

1. Sahih, berarti penilaian didasarkan pada data yang mencerminkan kemampuan yang diukur;

2. Objektif, berarti penilaian didasarkan pada prosedur dan kriteria yang jelas, tidak dipengaruhi subjektivitas penilai;

3. Adil, berarti penilaian tidak menguntungkan atau merugikan peserta didik karena berkebutuhan khusus serta perbedaan latar belakang agama, suku, budaya, adat istiadat, status sosial ekonomi, dan gender.

4. Terpadu, berarti penilaian oleh pendidik merupakan salah satu komponen yang tak terpisahkan dari kegiatan pembelajaran;

5. Terbuka, berarti prosedur penilaian, kriteria penilaian, dan dasar pengambilan keputusan dapat diketahui oleh pihak yang berkepentingan.

6. Menyeluruh dan berkesinambungan, berarti penilaian mencakup semua aspek kompetensi dengan menggunakan berbagai teknik penilaian yang sesuai, untuk memantau dan menilai perkembangan kemampuan peserta didik; 
7. Sistematis, berarti penilaian dilakukan secara berencana dan bertahap dengan mengikuti langkah-langkah baku;

8. Beracuan kriteria, berarti penilaian didasarkan pada ukuran pencapaian kompetensi yang ditetapkan; dan

9. Akuntabel, berarti penilaian dapat dipertanggungjawabkan, baik dari segi mekanisme, prosedur, teknik, maupun hasilnya.

(Lampiran Permendikbud 23: 2016, 5)

\section{Bentuk Penilaian}

1. Penilaian hasil belajar oleh pendidik dilakukan dalam bentuk ulangan, pengamatan, penugasan, dan/ atau bentuk lain yang diperlukan.

2. Penilaian hasil belajar oleh pendidik digunakan untuk

a. Mengukur dan mengetahui pencapaian kompetensi Peserta Didik;

b. Memperbaiki proses pembelajaran; dan

c. Menyusun laporan kemajuan hasil belajar harian, tengah semester, akhir semester, akhir tahun dan/ atau kenaikan kelas.

3. Penilaian hasil belajar oleh satuan pendidikan dilakukan dalam bentuk ujian sekolah/ madrasah.

4. Penilaian hasil belajar oleh satuan pendidikan digunakan untuk penentuan kelulusan dari satuan pendidikan.

5. Satuan pendidikan menggunakan hasil penilaian oleh satuan pendidikan dan hasil penilaian oleh pendidik untuk melakukan perbaikan dan/ atau penjaminan mutu pendidikan pada tingkat satuan pendidikan.

6. Dalam rangka perbaikan dan/ atau penjaminan mutu pendidikan satuan pendidikan menetapkan kriteria ketuntasan minimal serta kenaikan kelas peserta didik. 
7. Penilaian hasil belajar oleh Pemerintah dilakukan dalam bentuk Ujian Nasional dan/ atau bentuk lain yang diperlukan.

8. Penilaian hasil belajar oleh Pemerintah dalam bentuk ujian Nasional digunakan sebagai dasar untuk :

a. Pemetaan mutu program dan/ atau satuan pendidikan;

b. Pertimbangan seleksi masuk ke jenjang pendidikan berikutnya; dan

c. Pembinaan dan pemberian bantuan kepada satuan pendidikan dalam upayanya untuk meningkatkan mutu pendidikan.

(Lampiran Permendikbud No. 23: 2016, 5 6)

\section{E. Mekanisme Penilaian}

Mekanisme penilaian hasil belajar oleh pendidik:

1. Perancangan strategi penilaian oleh pendidik dilakukan pada saat penyusunan rencana pelaksanaan pembelajaran (RPP) berdasarkan silabus;

2. Penilaian aspek sikap dilakukan melalui observasi/ pengamatan dan teknik penilaian lain yang relevan, dan pelaporannya menjadi tanggung jawab wali kelas atau guru kelas;

3. Penilaian aspek pengetahuan dilakukan melalui tes tertulis, tes lisan, dan penugasan sesuai dengan kompetensi yang dinilai;

4. Penilaian keterampilan dilakukan melalui praktik, produk, proyek, portofolio dan/ atau teknik lain sesuai dengan kompetensi yang dinilai;

5. Peserta didik yang belum mencapai KKM satuan pendidikan harus mengikuti pembelajaran remidi; dan 
6. Hasil penilaian pencapaian pengetahuan dan keterampilan peserta didik disampaikan dalam bentuk angka dan/ atau deskripsi.

Mekanisme penilaian hasil belajar oleh satuan pendidikan

1. Penetapan KKM yang harus dicapai oleh peserta didik melalui rapat dewan pendidik;

2. Penilaian hasil belajar oleh satuan pendidikan pada semua mata pelajaran mencakup aspek sikap, pengetahuan, dan keterampilan;

3. Penilaian pada akhir jenjang pendidikan dilakukan melalui ujian sekolah/ madrasah ;

4. Laporan hasil penilaian pendidikan pada akhir semester dan akhir tahun ditetapkan dalam rapat dewan pendidik berdasar hasil penilaian oleh Satuan Pendidikan dan hasil penilaian oleh Pendidik; dan

5. Kenaikan kelas dan kelulusan peserta didik dari satuan pendidikan ditetapkan melalui rapat dewan pendidik.

Mekanisme penilaian hasil belajar oleh pemerintah :

1. Penilaian hasil belajar oleh Pemerintah dilakukan dalam bentuk Ujian Nasional (UN) dan / atau bentuk lain dalam rangka pengendalian mutu pendidikan;

2. Penyelenggaraan UN oleh Badan Standar Nasional Pendidikan (BSNP) bekerjasama dengan instansi terkait untuk mengukur pencapaian kompetensi lulusan.

3. Hasil UN disampaikan kepada peserta didik dalam bentuk sertifikat hasil UN;

4. Hasil UN disampaikan kepada satuan pendidikan untuk dijadikan masukan dalam perbaikan proses pembelajaran; 
5. Hasil UN disampaikan kepada pihak-pihak yang berkepentingan sebagai dasar untuk : pemetaan mutu program dan/ atau satuan pendidikan; pertimbangan seleksi masuk jenjang pendidikan berikutnya; serta pembinaan dan pemberian bantuan kepada satuan pendidikan dalam upayanya untuk meningkatkan mutu pendidikan;

6. Bentuk lain penilaian hasil belajar oleh Pemerintah dapat dilakukan dalam bentuk survei dan/ atau sensus; dan

7. Bentuk lain penilaian hasil belajar oleh Pemerintah diatur dengan Peraturan Menteri.

\section{F. Prosedur Penilaian}

1. Penilaian aspek sikap dilakukan melalui tahapan :

a. Mengamati perilaku peserta didik selama pembelajaran;

b. Mencatat perilaku peserta didik dengan menggunakan lembar observasi/ pengamatan;

c. Menindaklanjuti hasil pengamatan; dan

d. Mendeskripsikan perilaku peserta didik.

2. Penilaian aspek pengetahuan dilakukan melalui tahapan :

a. Menyusun perencanaan penilaian;

b. Mengembangkan instrumen penilaian;

c. Melaksanakan penilaian;

d. Memanfaatkan hasil penilaian; dan

e. Melaporkan hasil penilaian dalam bentuk angka dengan skala 0-100 dan deskripsi.

3. Penilaian aspek keterampilan dilakukan melalui tahapan:

a. Menyusun perencanaan penilaian;

b. Mengembangkan instrumen penilaian; 